To cite this article: Rita Otibhor Salami, Abubakar Saka Katamba, Mohammed Abubakar Bitagi and Samuel Jimmy Udoudoh (2020) Enhancing Research Activities of Library and Information Science Educators in Nigerian Universities through Utilization of Academic Social Media. Information Impact: Journal of Information and Knowledge Management, 11:2, 62-70, DOI: dx.doi.org/10.4314/iijikm.v11i2.6

To link to this article: https://dx.doi.org/10.4314/iijikm.v11i2.6

\title{
Enhancing Research Activities of Library and Information Science Educators in Nigerian Universities through Utilization of Academic Social Media
}

\author{
${ }^{1}$ Rita Otibhor Salami, ${ }^{2}$ Abubakar Saka Katamba, ${ }^{1}$ Mohammed Abubakar Bitagi and ${ }^{2}$ Samuel Jimmy \\ Udoudoh \\ ${ }^{1}$ University Library Services, Federal University of Technology, Minna, Nigeria \\ ${ }^{2}$ Department of Library and Information Technology, Federal University of Technology, Minna, Nigeria
}

\begin{abstract}
The paper examines how academic social media utilisation can enhance research activities of Library and Information Science educators in Nigerian universities. The study highlighted the various research activities of Library and Information Science educators such as information gathering, collaboration, and dissemination of research findings and measurement of impacts. In addition, the authors elaborated on the benefits of academic social media such as Research gate, Academia.edu, Google Scholar, LinkedIn, Open Researcher Contributor Identity and Mendeley to include profile creation, information gathering, search for potential collaborators, instant research result dissemination, measurement of impact and management of research. The study stated that factors such as social influence, technical factors and personal factors can influence use of academic social media platforms.
\end{abstract}

Keywords Social media, Academics, Research

Library and Information Science, Educators

CONTACT Salami,R.O, Katamba,A.S, Bitagi,M.A, and Udoudoh,S.J r.otibhor@futminna.edu.ng University Library Services, Federal University of Technology, Minna and Department of Library and Information Science, Federal University of Technology, Minna, Nigeria

2020 The Authors Published with License by Information Impact 


\section{Introduction}

Library and information science (LIS) professionals have been faced with several challenges such as continuous change in technology, change in government policies, changing societal and individuals' information expectations. Library and Information Science Educators in Nigeria have great role to play in promoting the profession by conveying existing knowledge, providing competencies and skills and ensuring they consider the new roles potential information science professionals are likely to play in the society in the nearest future. However, Burneth (2015) stated that Library and Information Science Schools in many developing countries including Nigeria are not keeping abreast of the rapidly changing/growing digital environment and that their students are facing new knowledge and skills demands from employers. .

The importance of research in library and information science cannot be overemphasized. It leads to the creation of new knowledge and growth of the profession. (Adubasim, 2018).Sacchanand (2012) and Virkus (2012) argued that despite the importance of research to LIS profession, LIS Professionals are not heavily involved in research. This has resulted in inadequate attention from funding agencies and major publishing houses because LIS research does not seem to provide answers to big research problems (Sacchanand 2012; Virkus 2012). There is a continuing need for more and better research in the field of Library and Information Science. It is worthy of note that a key to a successful research is undergoing a painstaking research activity. A vibrant research activity can easily expose the deficiencies in a research that a researcher is undergoing or has completed. Despite the importance of conducting a vibrant research activity, Ononogho (2014) emphasized that most LIS professionals in Nigeria do not adequately embark on research activities that are often well thought out to address contemporary events in the society and the profession. In these ways LIS issues and critical thinking are not prominent and noticeable. Hence the need for library and information science educators to incorporate digital technology in their research activities so as to improve of their research such as academic social media (ASM).

ASM are sites that are exploited mainly by academics, researchers, and scholars. They are specific in nature because they are associated with academic activities. Academic social media can be employed in all processes of research activities, from identifying research opportunities to disseminating research findings or results (Miah, 2012). Examples of ASM are: Mendeley, academia.edu, Research-gate, google-scholar, LinkedIn and ORCID among others (Tai \& Pieterse, 2017). This paper seeks to find out how academic social media can enhance research activities of library and information science in Nigeria

\section{Research Activities of Library and Information Science Educators}

Library and Information Science Educators (LISE) are significant just like their counterparts in other various professions. They play significant role in the production of high quality LIS professionals who occupy a unique position in national development. According to Anyanwu et al (2013) library and information science educators are expected to impart the necessary skills to their students so that, after graduation they can function effectively in Libraries and other information related work settings with minimal supervision. Apart from this function, they are expected to engage in research and community development. Research leads to the creation of new knowledge, growth of the profession, improvement in decision making, problem solving, career advancement, self-fulfillment, curriculum review and development.(Sacchanard 2012; OmuoluabiIdoti \& Bozimo,2012)

It is important to note that Library and Information Science educators in Nigeria can only improve the quality and quantity of their research if they are able to actively engage in vigorous research activities. Obura and Kingongo-Bukenya (2011) posited that as a result of technology, infrastructure such as digital 
libraries, and other web-based information systems require LIS educators to engage in research activities to be able to adapt to the technological changes (Obura \&Kingongo- Bukenya, 2011). Research activities can be viewed as activities undertaken by library and information science educators from identification of research problems to utilization of research findings by stakeholders. The importance of conducting a vibrant research activity cannot be overemphasized. It helps to provide answers to research questions, it keeps a researcher up-to-date on recent development in his/her field, it helps to provide feedback on one's own work and provide information on the impact of a research finding. It is also an aid to reforming the research activities of library and information scientists. Malekabadizadeh (2009) opined that in most LIS research, little attention is paid to adapting or adopting theories. Creative thinking is not encouraged and training programmes did not often lead to rigorous research activities. Research activities in library and information science can be grouped into the following parameters: Information sharing, collaboration, dissemination of findings and measurement of impact.

One of the research activities LISE are expected to engage in is information gathering. LIS professionals are expected to gather enough information on the research problem they want to solve. This can be achieved through adequate literature search (reading print and online resources), attending conferences, seminars, webinars, workshops and also asking questions from peers who are based within and outside the country. This was corroborated by Ifejehet al (2018) who maintained that for a meaningful research to take place, researchers must be aware of the state of the existing knowledge and how to have access to information which will help them to build up their own theories and findings. It must be emphasized that a researcher should continuously gather information in other to be abreast of current trends in his/her field. Information gathering also involves personal communication with stakeholders. Tools for information gathering include administration of questionnaires, interviews and focus group discussions. Information gathering is also relevant in the planning stage of a research to enable a researcher to know if the question has already been answered. It also helps to identify the gap that will likely be filled. LIS educators can engage in personal communication with stakeholders through administration of questionnaire, conductcqwe4ing interviews and focus group discussions. This will enable a researcher have access to firsthand information in answering research questions, test hypotheses and theories. It is important also for researchers to identify funding opportunities during the process of information gathering. To undertake quality research, funding is very necessary

Collaboration is another research activity that library and information science educators should embark on. Collaboration can take place with colleagues within the department, colleagues in other institutions within or outside the country. LIS educators are also encouraged to partner with colleagues in other disciplines. When experts from different disciplines come together to share knowledge and solve problems they will be able to solve bigger research problems. Collaboration is now on the increase due to the following reasons: most funding agencies prefer collaboration, division of labour of research activities, capability to share resources, it also provides opportunity to learn from other disciplines, share risk management, it enables a project to be credible and valuable and also facilitates communication among researchers (Kyvik and Raynent 2017) . While Gichygu (2018) advocated that LIS educators need continuous collaboration due to the following reasons: changing patterns of funding research, the desire by researchers to increase their popularity and visibility, the need to gain experience and to train LIS students on research methodology in the most effective ways possible. Collaboration could take the form of coauthoring, knowledge creation, knowledge sharing and data sharing. Gichygu (2018) advocated that LIS educators need continuous collaboration as a result of the following reasons: changing patterns of funding research, the desire by researchers to increase their popularity and visibility, need to gain experience and to 
train LIS students on research methodology in the most effective ways possible. Collaborations can be more effective if library and information scientist create research groups among colleagues within the profession and/ or outside the profession and be active participant. They are also encouraged to create research groups with the following professionals; Methodologist, Information and Communication Technologist, Statisticians, Measurement and Evaluators, Agriculturist, Law Professionals and Educationist among others. In addition, research activity cannot be complete if research findings are not disseminated to intended audience. Therefore, dissemination of research findings is another research activity in the field of Library and Information Science. Dissemination of research findings is getting the findings of a research to a targeted audience in order to make maximum use of it (National Institute for Health Research, 2019). Edward (2015) opined that several media can be utilized in dissemination of research findings such as publication in peer reviewed journals, presentations at professional meetings, oral presentation or poster presentation. It is also important for library and information science educators to make presentation among themselves before presenting or publishing such results in journals, conference papers and poster presentations. This will result in quality research as corrections and inputs will be made. Such manuscripts presentations can take place in school board meetings, departmental meetings, in-house seminars and workshops. Kanji (2015) maintained that no researcher is an expert in every facet of a research process. A researcher therefore needs advice from colleagues, methodologist and statisticians among others.

Another research activity undertaken by library and information science educators is measurement of impact. The Australian Research Council (2019) views research impact as the impact that research findings make to a society in terms of economy, culture, national security, public policy, services. It is not just enough for a researcher to undergo a research and publish its findings. It is equally very important to monitor the impact of such findings to stakeholders. There are several elements that can be employed in measuring the impact of a research. New City State University Library (2020) states that research impact is measured through such metrics as citation counts, h-index, and journal impact factors. Bornmann (2016) maintained that peer review process remains the backbone of measuring impact of a research finding for it ensures that research outputs meet certain standards to enable credibility and reliability. In a nutshell, research activities of library and information science educators can be grouped into four parameters these include: information gathering, collaboration, dissemination of findings and measurement of impact.

\section{Enhancing Research Activities Through Utilization of Academic Social Media Platforms}

Library and Information Science Educators are expected not only to strive to engage in research activities, rather they should also undergo research activities which in the end will provoke further reading, more reads, sharing, discussion, investigation and use by several stakeholders in the society. This is obtainable when library and information science educators leave their comfort zone and utilize various technologies like the academic social media in enhancing their research activities. Jamili et al (2015), defines academic social media as platforms that enable researchers to communicate, network and share documents with several people regardless of location, at little or no cost. It is worthy to note that academic social media has enabled researchers to limit geographical background and scholars can interact, communicate, debate, collaborate and create knowledge together.

The impact of academic social media in enhancing research activities cannot be overstated. The utilisation of academic social media has resulted to structural changes in research such as open science 2.0 initiatives, open access publishing, open data, and open peer evaluation systems. Academic social media can enhance research activities through the following ways; 
- Profile Services: The first and most important characteristic of academic social media is the provision of profile services. This serves as an online resume for researchers. Information that is usually contained in an academic social media profile page includes bio- data, photo, professional competence, research interest and current research project. Academic social media profile enables a researcher to improve his exposure, visibility, connect with other researchers and improves a researcher's reputation.

- Information gathering: It is worthy to note that several academic social media platforms such as Research gate, Academia.edu. Google Scholar, provide a medium for researchers to consume information for their research. Ward et al (2015) opined that academic social media perform literature -related function; such as searching for academic literature, tracking of relevant articles to read, for it gives access to publication lists and database entries of members, bibliographies; open access archive; various attention direction services like notifications "Have read" buttons, commenting or rating, "share this" function, among others. Academic social media provides forums for library and information educators to seek for advice from the community. They can also ask for help on ongoing research from colleagues by circulating draft forms of manuscript for comments. It is worthy to note that communities in academic social media platforms are usually boundless. Library and information science educators who have no access to current articles as a result of lack of accessibility to various databases can seize the opportunity provided by academic social media platforms to access millions of articles mostly for free.

In addition, several academic social media platforms can be used to generate data. Library and information science educators can employ the use of such platforms to collect their data, such as administering questionnaire, conducting interview, observation and content analysis especially when research stakeholders are members of an online community. Lupton (2014) maintained that academic social media is a platform that can be utilized by researchers to invite interested academics to complete a survey. Furthermore, academic social media also provide opportunity for researchers to be informed on funding opportunities and upcoming conferences, seminars and workshops in their field. For example, academia.edu alerts their members of funding opportunities and upcoming conferences, seminars and workshops available in various fields.

- Collaboration: It is no gain saying the fact that researches conducted by a single scholar are gradually disappearing. Tai and Pieterse (2017) maintained that academic social media provide opportunity for researchers to involve in collaboration among colleagues within the country and outside the country. It also makes it possible for researchers to engage in cross disciplinary collaboration. It is worthy to note that library and information science educators can find potential collaborators from academic social media platforms such as academia.edu, Researchgate, Mendeley, Linkedin and Open Researcher and Contributor Identity(ORCID)

- Dissemination of Research Findings: It is very important for a researcher to share what they have discovered with stakeholders. Traditionally, library and information science professionals in Nigeria disseminate their research findings in publications such as journals, book production, and conference papers among others. These publications are mainly accessed in various libraries and databases. However, several stakeholders and policy makers do not have access to such research findings. Chisenga et al. (2013) advocated that in Africa where access to research outputs generated in universities and research organizations is a challenge, academic social media has the potential to enhance the search for, distribution and sharing of research results. Consequently, the academic 
social media such as Google scholar, Research gate, Mendeley, Academia.edu are complementing these various methods of research dissemination since it makes it faster and possible for library and information science educators to communicate results directly to the public and other key stakeholders. Library and Information Science professionals are encouraged to post their full text articles, abstracts, data, manuscripts, posters presentations and slide presentation.

on a society in terms of economy, culture, national security, public policy, services, health, environment and improvement in quality of life. Traditionally, Library and Information Science educators' research productivity impact is measured by number of citations in their works, publication in impact factor journals and peer review content. It is no gain saying the fact that the traditional method of measuring impact is slow. It sometimes takes several years for a researcher's work to get cited. University of Malaya (2017) states that millions of researches are published by different journals and indexed in various databases such as Web of Science (WOS) and Scopus, however, over $43 \%$ of journals indexed by WOS have never received any citations. Library and information science educators are encouraged to share their research findings in various academic social media platforms. This implies that presentations and conference presentations in various academic social media platforms.

- Measurement of Impact; Australian research council (2019) views research impact as the impact that research findings makes single work can be shared in multiple academic social media platforms. It is worthy to note that various academic social media platforms such as. Google scholar, academia.edu, research gate and Mendeley use Almetric to measure the impact of a work. Almetric provides information on the number of citations, discussions and recommendations surrounding a work. Ravenscroft (2017) noted that traditional metrics such as h-index and g-index measure impact based mainly on citation of scientific work while academic social media have provided new cues to assess academic impact of scholars. For it allows users to tag, annotate, bookmark and rate scientific literature.

- Managing Research: Unlike traditional method of managing research that is slow and cumbersome, managing research on ASM is faster and easier. Furthermore, various platforms such as Googlescholar, Researchgate, Academia.edu and Mendeley provide tools that library and information science professionals need to save their research outputs. Also, platforms such as Open Researcher and Contributor Identity (ORCID) and Research ID, according to Bisset (2019) enable researchers to register and obtain a unique researcher ID number. Users can update their profile on the site and build their publication list. In order to undergo big researches, library and information science educators need to register with ORCID. This is because most editors, publishers and funding agencies require a researcher's ORCID number.

\section{Factors Affecting Use of Academic Social Media in Enhancing Research Activities}

The importance of academic social media in enhancing research activities have been extensively discussed in this paper. However, several factors have influenced the use of such platforms in enhancing research activities including:

Social Influence: Encouraged or recommended by friends, colleagues, one's institution has a strong positive impact in the use of academic social media platforms. To Zhu (2017) members may utilize academic social media based on their social identity which they see as an obligation of being members of an online community. 
- Technical Factors: lack of availability of mobile devices (Android, Tablet), personal computers, inadequate trainings, poor internet network, plagiarism and lack of social media policy can greatly affect the utilization of academic social media by users and non-users (Zhu, 2017).

- Personal Factors: Personal factors such as experience may possibly impact the adoption of academic social media by library and information science educators. Also, the age of the user may also influence the use of internet. Those born in the digital age are likely to be more enthusiastic in using novel technology. A user may also use it based on personal preference. Kumar (2015) observed that the following personal factors may also enhance the use of academic social media by researchers; too many social media tools to learn, lack of knowledge on how to use them. Also, health issues such as poor sight and backache may also affect the use of these platforms in enhancing research activities.

\section{Conclusion}

The paper was an overview on how academic social media can enhance research activities of library and information science educators in Nigeria. The author initially discussed the research activities of library and information science educators which include information gathering, collaboration, dissemination of research finding and measurement of impact. In order to conduct novel and vibrant research, library and information science educators are encouraged to employ use of various academic social media to enhance their research activities. The benefits of academic social media in research cannot be overemphasized. Such benefits include: creating profile which will lead to increase visibility, showcasing expertise and achievements. Other benefits of academic social media are: information gathering, finding potential collaborators or research teams, instant dissemination of research findings, measurement of impact and management of research Academic social media is extremely important for it encourages sharing of papers and making of input among colleagues. Furthermore, it provides opportunities for Library and Information Science educators to have access to millions of articles. Academic social media can be underutilized or not utilized due to factors such as social influence, personal and technical factors.

For effective utilisation of academic social media by Library and Information Science educators, the following are essential: provision of ICT infrastructure such as increase bandwidth, university management should consider how to make laptops and mobile phones (Tablets, Android) available for LIS educators for this will boost the frequency of usage, LIS educators should ensure they create multiple profiles in order to have access to services provided by various academic social media platforms and they should ensure they attend regular trainings, seminars, conferences and workshops on academic social media use. It is also vital for library and information science educators in Nigeria to actively engage in academic social media platforms in order to engage in novel and vibrant research activities. This will lead to improvement in the quality and quantity of research output in the field of library and information science profession. 


\section{References}

Adubasim, I.E (2018). Knowledge creation as predictor of employee. Retrieved $3^{\text {rd }}$ August, 2019 from www.globalscientificjournal.com

Anyanwu, E.U: Oduagwu, E.A: Ossai-Onah, O.V \& Amaechi, N.M (2013). Repositioning library and Information science graduates in Nigeria for self-employment through entrepreneurship education. American International Journal of Contemporary Research. 3(8) 178-184

Australian Research Council (2019) Engagement and impact assessment. Retrieved $6^{\text {th }}$ May, 2020 From https//www.arc.gov.ac

Bisset, J (2019). ORCID, ResearcherID and Scopus Author ID. Retrieved on $8^{\text {th }}$ May, 2020 from https://www.dur.ac.uk

Burneth, P (2013\}. Challenges and problems of library and information. Retrieved $8^{\text {th }}$ April, 2020, fromwww.library.ifla.org

Bornmann, L. (2016 \}. Measuring impact in research evaluations: a thorough discussion of methods of methods for, effects of and problems with impact measurements. Retrieved $2^{\text {nd }}$ January, 2020 from https//links.springer.com

Chisenga, J, Kademi, R, \& Sam, J. 2018. The Use of Social Media in Agricultural Workflows in Ghana and Kenya. Retrieved on $9^{\text {th }}$ May, 2018, from: www.journals.sfu.ca.aginfo.article

Edward, J. D (2015). Dissemination of research results on the path to practice change. Retrieved $18^{\text {th }}$ March, 2019 from https://www.nim.nih.gov

Gichygu, M.U (2018). Status of Information science faculty and collaboratory research in selected KenyaUniversities. Retrieved $5^{\text {th }}$ January, 2020, from https://lr-library.ku.ac.ke

Ifejeh, B.A; Ogbomo, M.N; \& Ifijeh, G (2018). Utilisation of academic resources for research productivity among lecturers in private universities in South-South Nigeria. Retrieved $16^{\text {th }}$ June, 2020 from http://digitalcommons.unl.edu/libhilprac//2071

Jamali, H.R, Nicholas, D \& Herman, E. (2015). Scholarly Reputation in the Digital Age and the role of Emerging Platforms. Retrieved on $11^{\text {th }}$ April, 2018, from: https//academic.oup.com

Malekabadizadeh, F; Shokraneh, F \& Hosseini, A (2009). The role of library and information science education to national development. Retrieved $25^{\text {th }}$ February 2020, from https//digitalcommons.uni.edu

Kanji, S (2015). Turning your research idea into a proposal worth. Retrieved $15^{\text {th }}$ May, 2017 From http/ncbi.nim.nih.gov

Kumar, C.R (2015). Social networks impact on academic libraries in technology era. International Journal of Libraries in Technology Era 5(3)101-108

Kyvik, S \& Ramet, I (2017). Research collaboration in groups and networks: differences across academic fields. Retrieved $6^{\text {th }}$ July, 2018 from http//www/linkspringer,com

Lupton, D. (2014). Feeling Better Connected: Academics use of Social Media. Retrieved on $16^{\text {th }}$ March, 2018. From: http/www.canberra.edu.au/about/uc/faculties/artdesign

Miah, A. (2012). A-Z of Social Media. Retrieved on $2^{\text {nd }}$ July, 2017, from: www.andymiah.netNational Institute for Health Research (2019). How to disseminate your research findings Retrieved $19^{\text {th }}$ June, 2020 from https//www.nihr.ac.uk

New City-state University Library (2020) How to measure researcher's impact. Retrieved $5^{\text {th }}$ April, 2020from https://ww.lib.ncsu.edu.your-mpat

University of Malaya,( 2017) Increasing visibility and enhancing impact of research. Retrieved on $18^{\text {th }}$ November, 2019 from https://plys.org/news/2017-o4-visibility-impact

Obura, C.O \& Kingongo-Bukenya, I.M.N (2011). Library and information science education in 
Uganda: Trends challenges and the way forward. Retrieved January, $5^{\text {th }} 2019$ from Doi/0.115/2011/705372

Omolluabi-Idioti \& Bozimo, D.O (2012). Research productivity of librarians in university libraries In Nigeria: A festschrift honour of Prof. Sam. E. Ifidon. Agege:Lagos. Elis Associate

Ononogbo, R.O (2015). Contempory issues in library and information science education: The Nigerian experience and sustainability thereof. In U. Nwokocha \& M.G Ochogwu (ed) Contemporary issues in library and information science education in Nigeria (pg1425)Umuahia: Zeh Communication

Ravenscoft, J; Liakata. M; Clare, A \& Duma, D (2017). Measuring scientific impact beyond Academia: an assessment of existing impact metrics and proposed improvements. Retrieved $9^{\text {th }}$ June, 2020 from www, anals.plos.org

Sacchanand, C (2012). Building collaboration between library and educators and practitioners in Thailand: transcending barriers, creating opportunities. Retrieved $8^{\text {th }}$ February from http://conference.ifla.otg

Tai, H.M. \& Pieterse, D. 2017. Why do Academics use Academic Social Networking Sites? Retrieved on $13^{\text {th }}$ June, 2017, from: www.irrodi.org.

Ward J, Bejarano, W, and Dudas, A.2015. Scholarly social media profiles and libraries. Are view. Retrieved $1^{\text {st }}$ November, 2019 from https/www.libraryquarterly.eu/article/10.18352/1q9958

Zhu, Y (2017). Academics active and passive use of YouTube for research and leisure. Retrieved February, $18^{\text {th }} 2020$ from https//www.igi-global.com 